cumstances here set forth would, we declare, be a calamity to English science and a scandal to the English Government. With the power to avert this in your hands, we appeal to your justice to do so. The difficulty of removing the directorship of Kew from the Department of Works cannot surely be insuperable; or if it be, it must be possible to give such a position to the Director, and such definition to his duties, as shall in future shield him from the exercise of authority which has been so wantonly abused.

\author{
Charles I,YelL \\ Charles DarWiN \\ JAMES PAgET \\ William SPotTiswoode \\ T. H. HUXLEY
}

Grorge Bentham, Pres. Linn. Society

HenRy Holland, Pres. Royal Institution

Grorge Burrows, Pres. Roy. Coll. of Physicians

GEORGR BusK, Pres. Roy. Coll. of Surgeons

H. C. Rawlinson, Pres. Roy. Geogr. Society

JOHN TYNDALL

\section{PROFESSOR AGASSIZ'S SOUTH AMERICAN EXPEDITION}

I.

PROF. AGASSIZ'S Second Report to Prof. B. Peirce, Superintendent of the United States Coast Survey, dated U.S. steamer Hassler, Concepcion Bay, June I, is given in the Nivi York Tribune of June 26 . The Report is of so great value and interest, that we reprint it entire :-

Since I sent my first report concerning erratics in the Southern Temperate Zone, I have been much engrossed with this subject, and have turned my attention chiefly that way, leaving to Pourtales the superintendence of the dredging, and to Steindachner and Blake the care of the zoological specimens.

On the eastern coast of Patagonia I had but little opportunity of adding to the information I had already obtained at Monte Video. It was not till we put into San Mathias Bay for some repairs that I could gather a few new facts. This bay is particularly interesting, because one can there compare the position of the tertiary beds in the cliffs bordering the Atlantic with that of similar beds in the cliffs along the northern shore of the bay. The southern exposure of the latter runs for nearly a hundred miles at about right angles with the sea coast. In both cases the outcrops of the beds are so nearly parallel with the surface of the sea, that whatever may have heen their changes of level with reference to the ocean, they still retain the horizontal position in which they were deposited. It is of the utmost importance to remember this point when considering the distribution of the erratics over this part of the country with reference to the agency that may have transported them to their present resting-place. Among these tertiary deposits are wellmarked banks of colossal oysters of considerable extent, one of which coincides with the level of low water, while another stands at least twenty-five feet higher. The difference of level between these two great beds of oysters is so considerable as to suggest a subsistence of the sea bottom during the deposition of the tertiary beds. Higher up there are outer layers full of smaller fossils-some about ten, others about twenty feet above the second oyster-bed. The oyster-beds are perfectly parallel with one another, and separated by thin layers of clay and sand. And so, also, are the upper tertiary beds containing the smaller fossils. Among these, one bank consists almost entirely of large numbers of a species of Scutella with a single perforation in the posterior interambulacral area. This bank is particularly well marked. A bank of hard sand higher up is also conspicuous, and so is another of hard clay standing about 100 feet above the sea-line.

As we shall see hereafter, and as Darwin has already stated, these tertiary beds extend all over eastern Patagonia, including the Straits of Magellan as far as Sandy Point. In consequence of disintegration the harder beds form as many retreating shelves, like stairs, upon the slope of the shore bank. Wherever surface denudation has taken place these shelves give rise to terraces, stretching horizontally at various heights all over the plains of Patagonia. The scenery at Cliff End reminded me somewhat of Gay Head and its tertiary formation, except that the upper part of the Cliff consisted chiefly of sandy clays, alternating with which are two distinct horizontal beds of considerable thickness, formed entirely of pebbles, rather small and uniform in size. These pebbles vary from the dimensions of a pea or a hazel nut to that of the fist, or more; but there are no boulders or large fragments of rock among them. It is noteworthy that, while these pebbles alternate in regular stratification with the sandy clays in the upper part of the cliff, they also occur upon the shelves below. In the latter case, however, they form only superficial deposits, and do not penetrate with the beds on which they rest into the interior of the strata. It has occurred to me that similar superficial accumulations of pebbles upon the shelves bordering the bed of the Santa Cruz River may have been mistaken by Darwin for indications of successive upheavals. It is certain that there are no beaches here, marking successive steps of the upheaval of the country. What Darwin has considered as evidence of a gradual rise of the shore are the denuded surfaces of the horizontal tertiary deposits which everywhere form parallel terraces. As formyself, I see here no evidence of upheaval except the level of the fossil beds of oysters and other fossils in the tertiary beds above the water, and the presence of fresh shells of living species upon and above the shore banks. 'These, however, only indicate that an upheaval has taken place since the deposition of the tertiaries, and while the shells now living already existed, without pointing to the rise by successive steps. Still less does it appear to me that the country has been submerged during the transposition of the erratics. Toward the west end of San Mathias Bay, at Port San Antonio, where extensive denudations have taken place in the very formations here described, these same pebbles occur again. But at Port San Antonio, instead of being well defined, continuous horizontal beds above the sea-level, they are shore pebbles, covering in a deep layer the whole extent of the beach, the inequality of which they follow. Their position here shows, beyond the possibility of doubt, that the whole set of beds above which they rest in regular stratification at Cliff End has been completely broken down and recently removed by the action of the sea, and the pebbles themselves thus brought to the sea level. Of course it follows that these pebbles have not been ground upon the modern beach, but upon an older foundation, corresponding at the time to the level at which the pebble beds now stand at Cliff End.

So far the facts. I am inclined to add, as an inference from subsequent observations made farther south, the relation of which to the facts above stated seem to me clear, that these pelbbles have passed through the mill of a glacier's bottom before they were worked up by the floods into their present position in the beds of Cliff End and upon the beach of San Antonio ; and I do not see why the floods which formed these denudations could not as well have been the result of the melting of ice at the close of the glacial period, as the result of a change of level between land and sea. As soon as geologists have learned to appreciate the extent to which our globe has been covered and fashioned by ice, they may be less inclined to advocate changes of level between land and sea, wherever they meet with the evidence of the action of the water, especially where no marine remains of any kind mark the presence of the sea. As I have already said, the small and remarkably uniform size of the pebbles in Port San Antonio is particularly noticeable, and also the fact that none but hard rocks, indeed, only the very hardest kind of rocks, are represented among them.

(To be continued.)

CONTENTS

Economic ENTOMOLOGY . . . . . . . . . . . 197

ORigin and Degtiny of Man . . . . . . . . . . . . rg8

Our Book Shely . . . . . . . . . . . . . . . . rg9 LetTers to the EDitor:-

The Rigidity of the Earth and the Liquidity of Lavas.--Prof. T. STERRY HUNT, F.R.S.

Fouling of the Nile.-Rev. Canon KingsLey, F.L.S. . . . 200

Volcanoes of Central France.-HENRY NoRTON . . . . . . 200

The Wanderings of the Esquimaux.-Dr. JoHN RAE, F.R.G.S. 200

The Aurora of February 4.-H. C. Russell. . . . . 202 The Zoologtcal Statjon at Naples ........ 202 ON ALPine Maps. By EDWA?D WhTMPER . . . . . . . . . 203 Evans's STONe Implements of GREAT Britain. I. (With Nllizs: on The Hunterian Museum . . . . . . . . . . . . 208 Notrs . . . . . . . . . . . . . . 209 Mr. Ayrton and Dr. Hooker . . . . . Pror. Agassiz's South American Expedition, I. ..... zir 